Article

\title{
Field Study on the Efficiency of a Methane Degradation Layer Composed of Fine Fraction Soil from Landfill Mining
}

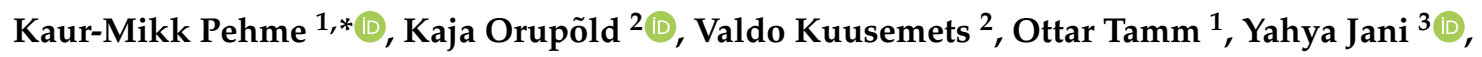 \\ Toomas Tamm ${ }^{1} \mathbb{D}$ and Mait Kriipsalu ${ }^{1}$ \\ 1 Institute of Forestry and Rural Engineering, Estonian University of Life Sciences, Kreutzwaldi 5, 51006 Tartu, \\ Estonia; ottar.tamm@emu.ee (O.T.); toomas.tamm@emu.ee (T.T.); mait.kriipsalu@emu.ee (M.K.) \\ 2 Institute of Agricultural and Environmental Sciences, Estonian University of Life Sciences, Kreutzwaldi 5, \\ 51006 Tartu, Estonia; kaja.orupold@emu.ee (K.O.); valdo.kuusemets@emu.ee (V.K.) \\ 3 Department of Biology and Environmental Science, Faculty of Health and Life Sciences, Linnaeus University, \\ 43081 Kalmar, Sweden; yahya.jani@lnu.se \\ * Correspondence: kaur.pehme@emu.ee
}

Received: 18 May 2020; Accepted: 29 July 2020; Published: 1 August 2020

check for updates

\begin{abstract}
The main components of landfill gas are methane and carbon dioxide. Emissions of methane, a strong greenhouse gas, can be minimized by in situ oxidation in the bioactive cover layer. Typically, organic-rich porous materials such as compost are used for this process. In this study, the material for a biocover was obtained from the same landfill by landfill mining. The objective was to study the spatial distribution of gases and the efficiency of methane degradation in the biocover. The methane and carbon dioxide emissions were measured at 29 measuring points six times on the surface and once at a depth of $0.5 \mathrm{~m}$. The highest values of both gases from the surface were recorded in July 2015: $1.0 \%$ for $\mathrm{CO}_{2}$ and 2.1\% for $\mathrm{CH}_{4}$. Deeper in the cover layer, higher values of methane concentration were recorded. The results showed that (a) methane from the waste deposit was entering the biocover, (b) the migration of methane to the atmosphere was low, (c) fluctuations in the composition of gases are seasonal, and (d) the trend in the concentration of $\mathrm{CH}_{4}$ over time was an overall decrease. The described cover design reduces the $\mathrm{CH}_{4}$ emissions in landfills using elements of circular economy-instead of wasting natural soils and synthetic liners for the construction of the final cover layer, functional waste-derived materials can be used.
\end{abstract}

Keywords: landfill gas; methane emissions; in situ methane oxidation; landfill mining

\section{Introduction}

\subsection{Landfill Emissions}

Landfill gas (LFG) is a by-product of the anaerobic biological decomposition of organic material in wastes. It contains $\mathrm{CH}_{4}(55-60 \mathrm{vol} \%) ; \mathrm{CO}_{2}(40-45 \mathrm{vol} \%)$; and traces of non-methane organic compounds (NMOCs) at low concentrations, including alkanes, aromatics, chloro-fluoro compounds (CFCs), alkenes, alcohols, ketones, terpenes, siloxanes, and others. In the monitoring of landfill gas and depending on data availability, the greenhouse gas emission potential can be determined by measuring the methane concentration [1,2], gas production (flux), or the share of degradable organic matter. The components of anthropogenic gases remain in the atmosphere for $12\left(\mathrm{CH}_{4}\right)$ to $172\left(\mathrm{CO}_{2}\right)$ years, thus seriously contributing to climate change. The radiative capacity of methane is $3.79 \times 10^{-4} \mathrm{~W} /\left(\mathrm{m}^{2} \mathrm{ppb}\right)$, compared to $1.4 \times 10^{-5} \mathrm{~W} /\left(\mathrm{m}^{2} \mathrm{ppb}\right)$ for $\mathrm{CO}_{2}$ [3]. Therefore, over a period of a century, as a greenhouse gas methane is 25 times more aggressive than $\mathrm{CO}_{2}$ [4], even though $\mathrm{CH}_{4}$ is 
relatively short-lived when considered in a long time frame [5]. Landfills are considered one of the major sources of anthropogenic methane. In Europe, methane from waste is estimated to account for $30 \%$ of total anthropogenic methane emissions [6] and, therefore, the importance of reducing methane emissions from landfills is obvious.

Gas quality and quantity are largely determined by waste composition and its degradable organic content, particle size, moisture, ambient temperature, and $\mathrm{pH}[7,8]$. Waste composition itself is determined by the locality, economic conditions, industry, traditions, and waste management techniques [9]. An increase in the moisture content may increase the landfill methane generation rate $[7,10,11]$. The $\mathrm{CH}_{4}$ production rate at any given point in time is influenced by the temperature, as is every biochemical reaction $[8,12,13]$. Several methodologies exist to estimate emissions while delivering cost- and labor-effective results $[14,15]$. Static and mobile plume measurement methods are conducted using tracer gas [16-18], differential absorption light detection and ranging (LiDAR) [19], and radial plume mapping with the optical remote sensing of laser infrared radiation emissions [15,20], as well as inverse plume modelling methodology [21,22], where a field survey can be carried out by walking in a gridded area with a Flame Ionization Detector or another field gas analyzer. Thus, emission hotspots and cracks in the landfill cover can be identified [23]. In this context, the determination of efficient approaches to correlate surface concentrations with the methane oxidation rates and emissions is crucial. In the case of landfills, the most commonly used measurement method is the static chamber method $[24,25]$. The principle of this method lies in the formation of a space enclosed in the gas emission surface, where the accumulated gas can be measured over time [26]. This is a relatively simple and inexpensive method for spot metering. In the method, the edges of the chamber are compressed in the soil [27] or applied to previously ground-mounted collars [24,28] to avoid gas leakage from the chamber during the measurement.

Modern landfills are typically highly engineered containment facilities with a focus on low-permeability capping and/or artificial multi-barrier lining systems where leachate and gas are collected and treated. However, low infiltration rates decrease degradation rates for organic matter and result in the slow flushing rates of leachate pollutants [29]. Extended aftercare timescales show the occurrence of a significant economic problem for hundreds of years before landfills reach the scientifically justified point known as the "Final Storage Quality" (FSQ) or "Completion", where it is guaranteed that no further management or monitoring of emissions is necessary [30]. A lack of certainty in the funding of long-term aftercare leads to environmental aim failures, as leachate pumping/removal and treatment are shut down or fail before the achievement of FSQ [31]. It is easier for the operator to reduce these timescales by avoiding a low permeability cap and allowing a higher flux of water to enter a mass. Uniquely, based on [32] landfill regulations in Ottawa, Canada, the installation of top covers must allow $>150 \mathrm{~mm}$ infiltration per year [33]. A more aggressive approach would be the addition of moisture to the waste- e.g., the controlled addition of recirculated leachate or other water sources. An increase in the moisture content enhances biodegradation processes in landfills [34-36] and promotes organic waste stabilization according to bioreactor technology adopted in the USA [37,38]. Several researchers $[29,39]$ insist that operators should implement accelerated completion trials, as was done in the Netherlands in 2016 [40].

\subsection{Biocovers}

$\mathrm{CH}_{4}$ emissions from landfills can be minimized by oxidizing them by methanotrophic bacteria in biocovers-biologically active landfill top covers $[25,41,42]$. The bacteria use methane as a carbon and energy source, resulting in the production of $\mathrm{CO}_{2}$ and $\mathrm{H}_{2} \mathrm{O}$ in exothermic processes (1):

$$
\mathrm{CH}_{4}+2 \mathrm{O}_{2} \rightarrow \mathrm{CO}_{2}+2 \mathrm{H}_{2} \mathrm{O}+882.6 \mathrm{~kJ} \text {. }
$$

Methanotrophic bacteria are most active in the upper zone of the landfill cover material [43]. Therefore, biocovers are made of porous organic-rich materials that support their growth and an inert gas 
distribution layer (e.g., gravel or coarse sand) with the main purpose of distributing gas evenly into the top-cover where methane is degraded [25,41]. Laboratory and field studies of biocovers are described in the literature [44-46], and several environmental variables, such as temperature and moisture content, as well as physical material properties are mentioned as important. The porosity, gas permeability, water holding capacity, diffusivity, and particle size distribution are the most important factors. Landfill gas and atmospheric oxygen both have to enter the biocover material, either by adjective flux or by diffusion. For organic-rich materials, the stability and maturity should be considered [25,47]. If the material contains easily degradable fresh compost, it may consume a large amount of $\mathrm{O}_{2}$, and this would exhaust the $\mathrm{O}_{2}$ that is needed for $\mathrm{CH}_{4}$ oxidation. Immature and unstable compost will also be more likely to produce $\mathrm{CH}_{4}$ under anaerobic conditions [25]. Previous studies [48-51] have stated that key factors in the control of the methane oxidation capacity within landfill cover soils are the soil organic content, texture, moisture, temperature, $\mathrm{pH}$, nutrient content, oxygen accessibility, and $\mathrm{CH}_{4}$ concentration. According to Huber-Humer et al. [42], the target values for biocover material should be as follows: total organic carbon (TOC) $>7 \% \mathrm{DM}$; organic content $>15 \% \mathrm{DM}$; respiratory activity in 7 days $<8 \mathrm{mgO}_{2} / \mathrm{g} \mathrm{DM} ; \mathrm{NH}_{4}-\mathrm{N}<400$ ppm DM; $\mathrm{P}_{\text {tot }}>0.3 \% \mathrm{DM} ; \mathrm{N}_{\text {tot }}>0.5 \%$ DM; conductivity $<4 \mathrm{mS} / \mathrm{cm}$; bulk density $0.8-1.1 \mathrm{~kg} / \mathrm{l}$; moisture content $30-50 \% \mathrm{w} / \mathrm{w}$; water holding capacity (WHC) $50-130 \% \mathrm{DM}$; air-filled pore volume $>25 \% \mathrm{v} / \mathrm{v}$; and particle size $<20 \mathrm{~mm}(90 \%)$.

Yamini and Reddy [52], as well as Scheutz et al. [18], have stated that it is difficult to quantify landfill fugitive methane emissions due to the high temporal variability and spatial heterogeneity of emissions, leading to this being one of largest sources for errors and uncertainties in biocover research. To reduce the uncertainties in research, various materials and mixtures with relatively uniform compositions have been used for biocovers-e.g., compost made of sewage sludge [53], biowaste [41,42,45,54-56], or green waste $[57,58]$, as well as the fine fraction (FF) from the Mechanical-Biological Treatment (MBT) of municipal waste $[47,59,60]$ [60]. Waste-based biocover materials are made of aged and stabilized refuse, and their properties are similar to those of humus soil [61].

Engineered biocovers have homogeneous particle sizes and active microorganism communities. The potential of methane oxidation in biocovers is highly dependent on their chemical and physical features, the age of the cover material itself, seasonal alterations, and the actual concentration of methane [62,63]. According to Börjesson et al. [53], mature sewage sludge has a better ability to undergo methane degradation (oxidation) compared with fresh sewage sludge, mineral mud or clay, and fresh sewage sludge mixture. Mineral soils also have a lower efficiency than matured sludge [55]. Effective methane oxidation is obtained in a cover layer consisting of sewage sludge compost and peat mixture [45].

The chemical and biological factors of the cover material, such as the content of nutrients and the respiratory activity of the materials, impact $\mathrm{CH}_{4}$ oxidation $[25,42]$. The methane degradation rate has been reported to vary from $10 \%$ to $100 \%$ in different studies [64]. Therefore, the optimization of the cover material properties is crucial. Mosier [65] suggested that measuring only the physical parameters could be enough to determine the oxidation rate. Albanna et al. [66] reported that an increase in layer thickness from 15 to $20 \mathrm{~cm}$ enhances the oxidation process by several percent.

The aim of this research was to study the efficiency of a methane degradation layer composed of material obtained during the Kudjape landfill mining and closure project in Estonia. The novelty of the biocover research is its synergy of two aspects. First, a soil-like fine fraction which was excavated from the same landfill was used as the biocover. Similarly, in the study by Jain et al. [60], an area of 6.8 ha was covered with $126,350 \mathrm{~m}^{3}$ of material taken from the landfill. He et al. [61] showed that the oxidation activity of the soil sieved from a three-year simulated landfill reactor was 10 times higher than that of clayey soil. Second, the functional use of the excavated fine fraction would open the door for the use of the concept of recovering resources from old landfills. Typical recoverable materials are metals, plastic and other combustibles, and mineral materials (stones, glass). One of the main barriers to landfill mining is the lack of use of the fine fraction $[60,67,68]$. 


\subsection{Description of the Site}

The Kudjape Landfill is located in Estonia on the Island of Saaremaa (N 58:16:06, E 22:32:23), $2 \mathrm{~km}$ southeast from the town of Kuressaare and $1.6 \mathrm{~km}$ from the coastline of the Baltic Sea (Figure 1). The landscape structure and appearance is diversified by beach ridges and mires between them. The bedrock is mostly limestone, with a thin layer of poor soil on top of it. The landfill neighborhood is mostly covered by forest, with a small amount of cultivated land [69]. The average annual temperature at the site is $5.6^{\circ} \mathrm{C}$, and the annual precipitation is $594 \mathrm{~mm}$ [70]. For the six measuring occasions, the meteorological conditions were as follows: air temperature $1.1-16.0{ }^{\circ} \mathrm{C}$, humidity $58-94 \%$, air pressure $1012.9-1030.9 \mathrm{mbar}$, wind speed $2.1-11.2 \mathrm{~m} / \mathrm{s}$, and precipitation $0.0-1.1 \mathrm{~mm} / \mathrm{h}$.

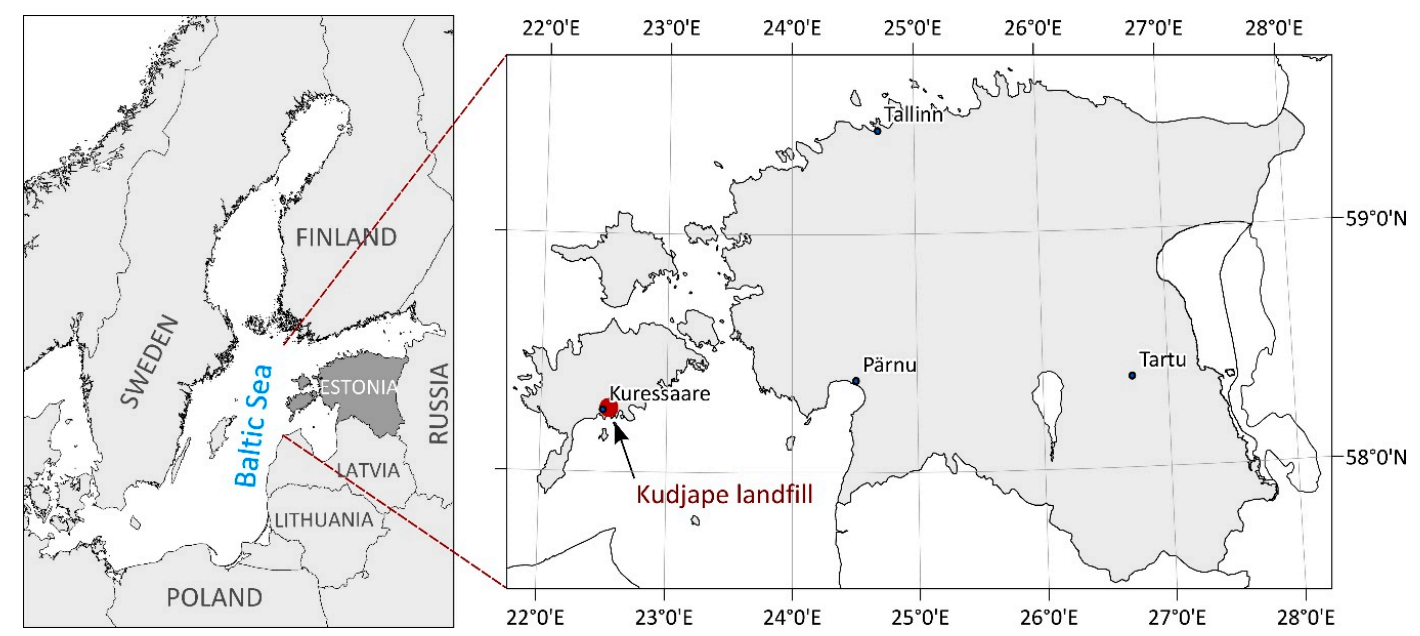

Figure 1. Location of the Kudjape landfill.

The estimated volume of waste in the Kudjape Landfill is about 193,000 $\mathrm{m}^{3}$ [70]. The dumping area consisted of two unlined sections: (1) the old section of approximately 1.2 ha that received an estimated waste volume of 35,000 $\mathrm{m}^{3}$ between 1970 and 2000; and (2) the new section of approximately $2.7 \mathrm{ha}$, with an approximate volume of $158,000 \mathrm{~m}^{3}$ of disposed waste which was received between 2000 and 2009 [70]. The waste was dumped on a flat area, $4 \mathrm{~m}$ above sea level with a total height of $12 \mathrm{~m}$ before closure. The waste was compacted by a compactor during the last years of operation. The Kudjape municipal landfill received no intermediate cover layers. A thin layer of gravel has covered a flat area of the landfill since 2009, but the slopes remain uncovered [68]. No collection or treatment system for leachate and gas exists at the landfill. The landfill has several sampling and monitoring wells for groundwater, as well as two gas wells [71]. According to law, the landfill had to be closed for disposal by 2009, and it had to have a final cover layer by mid-2013.

\subsection{Design of a Biocover}

The plan was to use $60,000 \mathrm{~m}^{3}$ of material to cover the landfill with biocover. The method, where fine material was extracted from the same landfill for the construction of biocover, was necessitated by the fact that natural clay was not locally available, and the transportation of it from the mainland by trucks and ferries was considered unfeasible. Following legal requirements, the environmental authority covered the landfill with a $1.2 \mathrm{~m}$-thick methane degradation layer, accompanied by an $0.5 \mathrm{~m}$ layer of coarse mineral fraction for gas distribution (Figure 2). 


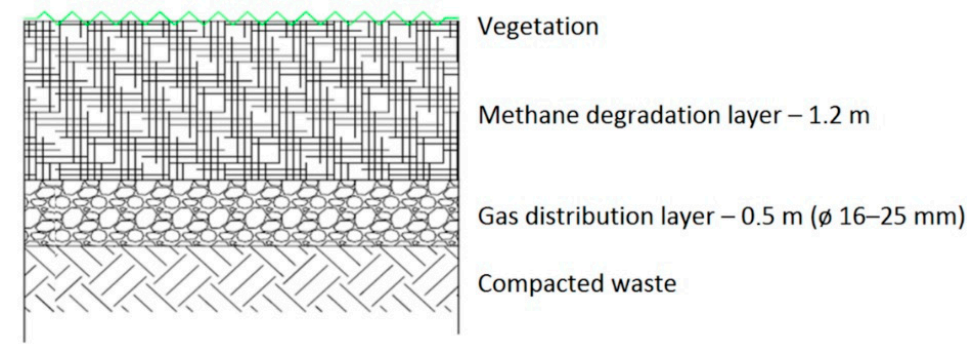

Figure 2. Design of the biocover layer at the Kudjape landfill [72].

During the project, 1.9 hectares with $55,000 \mathrm{~m}^{3}$ of waste were excavated and sieved, and the resulting materials were: (1) material that was intended to be used to construct the cover layer (fine fraction, $\mathrm{FF},<40 \mathrm{~mm}$ ); (2) mineral material that was used as the gas distribution layer; (3) potential waste fuel (RDF); and (4) material that was not eligible for reuse, which was backfilled. The chemical properties of the FF were compared to the limit values for national ordinance for contaminated soil in industrial zones [73] and the target values developed by Huber-Humer et al. [42], as shown in Table 1. The limit value is a legally binding concentration of a hazardous substance in soil. For instance, the heavy metal content in the FF had to meet the limit value for contaminated soil [73], even if it was excavated and backfilled at the same location, and even if it did not affect the functionality of the methane degradation layer. The actual characteristics of the biocover (Table 1) represent the outcome of adjusting the composition of the biocover material according to Pehme et al. [74].

Table 1. Characteristics of the fine fraction (FF) and biocover constructed at the Kudjape landfill (average \pm standard deviation) compared with the limit values in soil for industrial zones set by the regulation in Estonia (Regulation, 2010) and the target values for biocover recommended by Huber-Humer et al. [42].

\begin{tabular}{|c|c|c|c|c|c|}
\hline Metal & Unit & Fine Fraction (FF) & Actual Biocover & Limit Value & Target Value \\
\hline Arsenic (As) & $\mathrm{mg} / \mathrm{kg} \mathrm{DM}$ & $5.0 \pm 0.9(17) *$ & $4.1(1)$ & 50 & \\
\hline Cadmium $(\mathrm{Cd})$ & $\mathrm{mg} / \mathrm{kg} \mathrm{DM}$ & $1.0 \pm 0.4(17)$ & $0.5(1)$ & 20 & \\
\hline Chromium (Cr) & $\mathrm{mg} / \mathrm{kg} \mathrm{DM}$ & $77 \pm 44(17)$ & $28(1)$ & 800 & \\
\hline Nickel (Ni) & $\mathrm{mg} / \mathrm{kg} \mathrm{DM}$ & $34 \pm 13(17)$ & $15(1)$ & 500 & \\
\hline Lead $(\mathrm{Pb})$ & $\mathrm{mg} / \mathrm{kg} \mathrm{DM}$ & $241 \pm 232(17)$ & $81(1)$ & 600 & \\
\hline Zinc (Zn) & $\mathrm{mg} / \mathrm{kg} \mathrm{DM}$ & $1590 \pm 843(17)$ & $360(1)$ & 1000 & \\
\hline Copper $(\mathrm{Cu})$ & $\mathrm{mg} / \mathrm{kg} \mathrm{DM}$ & $257 \pm 181(17)$ & $56(1)$ & 500 & \\
\hline Mercury (Hg) & $\mathrm{mg} / \mathrm{kg} \mathrm{DM}$ & $0.89(1)$ & $0.43(1)$ & 10 & \\
\hline Carbon / & & $31 \pm 4(2)$ & nd & & \\
\hline \multicolumn{6}{|l|}{$\begin{array}{l}\text { Nitrogen }(C / N) \\
\text { ratio }\end{array}$} \\
\hline $\begin{array}{l}\text { Dry matter } \\
\text { (DM) }\end{array}$ & $\%$ & $65.4 \pm 4.3(18)$ & $70.5 \pm 0.9(5)$ & & $50-70$ \\
\hline $\begin{array}{l}\text { Loss of Ignition } \\
\text { (LOI) }\end{array}$ & $\% \mathrm{DM}$ & $19.3 \pm 3.7(18)$ & $12.5 \pm 1.6(5)$ & & $>15$ \\
\hline $\mathrm{pH}$ & & $7.80 \pm 0.26(18)$ & $7.59 \pm 0.09(5)$ & & $6.5-8.5$ \\
\hline Electrical & $\mathrm{mS} / \mathrm{cm}$ & $2.62 \pm 1.25(18)$ & $1.17 \pm 0.68(5)$ & & $<4$ \\
\hline \multicolumn{6}{|l|}{$\begin{array}{l}\text { Conductivity } \\
\text { (EC) }\end{array}$} \\
\hline Total Organic & $\% \mathrm{DM}$ & $12.7 \pm 3.8(2)$ & $7.4 \pm 1.2(2)$ & & $>7$ \\
\hline \multicolumn{6}{|l|}{ Carbon (TOC) } \\
\hline $\begin{array}{l}\text { Respiration } \\
\text { activity (7 d) }\end{array}$ & $\mathrm{mgO}_{2} / \mathrm{g} \mathrm{DM}$ & $5.9 \pm 3.9(18)$ & $4.8 \pm 2.0(5)$ & & $\leq 8$ \\
\hline \multicolumn{6}{|l|}{$\begin{array}{l}\text { Water holding } \\
\text { capacity }\end{array}$} \\
\hline$(\mathrm{WHC})$ & g/100 g DM & $140(1)$ & $80(1)$ & & $>80$ \\
\hline
\end{tabular}

All the heavy metal values in the FF corresponded to limit values set by the Estonian regulation [73], except zinc. This finding required additional research on metal leaching from the FF and speciation in 
the FF to understand the mobility and potential bioavailability of the metals. The results obtained by Kaczala et al. [68] showed leaching of less than $0.2 \%$ for $\mathrm{Cd}$ and $\mathrm{Cr}$, less than $0.4 \%$ for $\mathrm{Cu}$ and $\mathrm{Zn}$, and $0.5-1.0 \%$ for $\mathrm{Pb}$ from the total content of the metals. Additionally, Burlakovs et al. [71] showed that, despite the occasionally high total concentration of some elements such as $\mathrm{Zn}, \mathrm{Pb}$, and $\mathrm{Cu}$, their water-soluble and acid-soluble fractions form a very small part of the total content of metals. Therefore, the mobility and potential bioavailability of these metals were considered low. It was also found that other heavy metals, such as $\mathrm{Cr}$ and $\mathrm{Cd}$, were present in negligible amounts in easily extractable and potentially bioavailable fractions [71]. The authority agreed that the FF was allowed to be used as the cover material.

The target values presented in Table 1 directly impact methane degradation; however, the values for heavy metals also have to meet legal requirements. Although the mean value of respiration activity of the FF (Table 1) was under the target value ( $\leq 8 \mathrm{mgO}_{2} / \mathrm{g} \mathrm{DM}$ ), some of the FF samples exceeded this criterion. A high organic matter content is favorable; however, material used for biocovers must be stable and mature. Materials which are not stable may cause oxygen depletion in the biocover, resulting in oxygen deficiency in methane oxidation or even the production of methane if anaerobic conditions develop. The high $\mathrm{C} / \mathrm{N}$ ratio (Table 1 ) shows that the organic carbon had not fully mineralized in the landfill. Chemical and hydrological tests performed in a previous study [74] showed the optimal composition of the biocover for methane degradation as consisting of $60 \%$ fine fraction from landfill mining, 20\% natural soil, and 20\% mature sewage sludge compost. The objective of such adjustments was to reduce biological activity by adding mineral soil with a low microbial content and to increase the content of stabilized organic carbon by adding mature sludge compost.

All remediation works with the biocover were completed by September 2013.

\section{Materials and Methods}

The measurement of the efficiency of the methane degradation layer could be carried out in different methods. Methane could be measured from the landfill surface or by detecting it several kilometers away, with a measurement duration from minutes to weeks or months. For evaluating the qualitative efficiency of the cover layer, the measurement of methane from the inside the landfill by the vertical gas concentration profiles and from the surface by closed surface flux chambers can give appropriate information about the efficiency of the cover layer and has been used in several previous studies $[28,59,75]$. Measuring methane at the surface excludes possible interference from surrounding methane sources. However, the method does not cover heterogeneous emissions from the surface, because it does not cover the whole landfill area [76]. To minimize that limitation, we used as many measurement points as possible. In addition, all the measurements were carried out by the same team, and the results of the less accurate portable gas analyzer were double checked by evacuated glass bottle samples analyzed in the laboratory under more accurate conditions.

The efficiency of the methane degradation layer was studied two years after the cover layer was installed. The measurements were carried out on the surface six times from July 2015 to April 2016, and once from depth of a $0.5 \mathrm{~m}$. The methane and carbon dioxide emissions through the cover layer were measured at 29 measuring points (Figure 3). The majority of the points were located within the waste disposal area. The exception was the outermost points (P1, P15, P16, P29), which were expected to provide background data, excluding the impact of waste.

Field measurements from the surface were carried out by the closed loop static chamber ( $40 \mathrm{~L}$ ) method (Figures 3a and 4a). During every monitoring event, every point was measured twice and the results were calculated as the difference in gas content between the two measurements. The first measurement was carried out immediately after the box was installed, and the other was taken $10 \mathrm{~min}$ later. The 10-min interval was selected on the basis of on-site tests, where the results from an interval of $20 \mathrm{~min}$ did not differ significantly. 


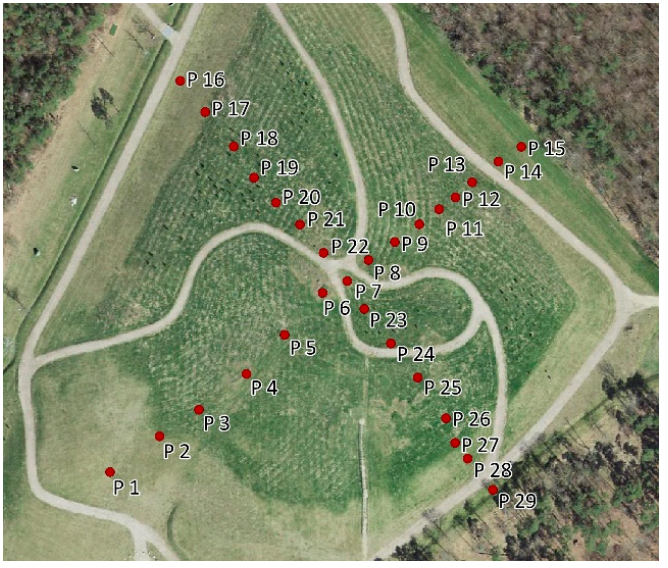

(a)

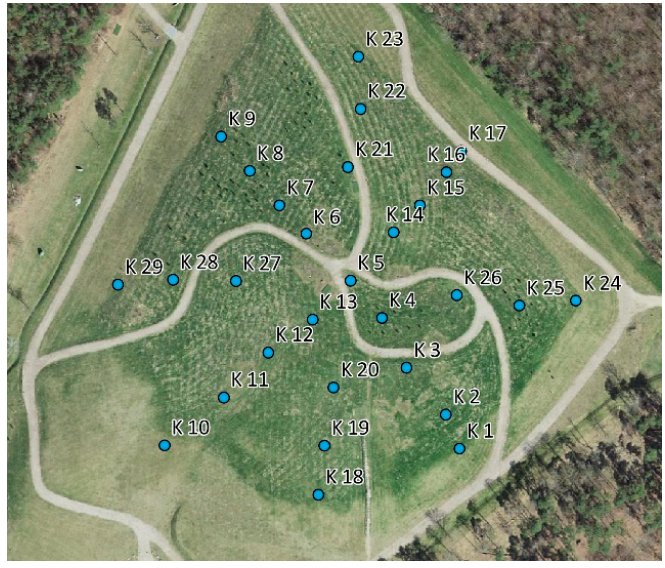

(b)

Figure 3. Gas measurement points at the Kudjape Landfill: (a) surface; (b) $0.5 \mathrm{~m}$ deep.

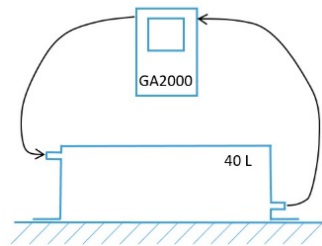

(a)

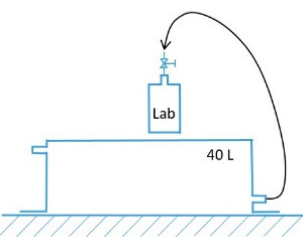

(b)

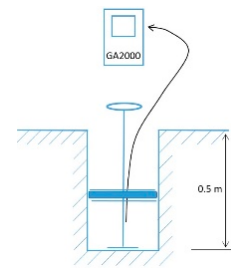

(c)

Figure 4. Schematic of measurement methods: (a) in situ from the surface of the biocover; (b) lab sample from the surface of the biocover; (c) in situ $0.5 \mathrm{~m}$ deep in the biocover.

Laboratory gas samples were collected in October $2015 \mathrm{in} 100 \mathrm{~mL}$ evacuated glass bottles. Samples were collected from 29 measuring points on the surface (Figures $3 a$ and $4 b$ ). Similarly, every point was measured twice. The first bottle was filled immediately after the box was installed, and the second one was filled 10 min later.

On the same date, $200 \mathrm{~mm}$ boreholes were drilled $0.5 \mathrm{~m}$ deep into the biocover at 29 spots. A sampling device was designed to block airflow into the sampled volume and allow the intake of gas from the specified depth of $0.5 \mathrm{~m}$ (Figures $3 \mathrm{~b}$ and $4 \mathrm{c}$ ).

A portable gas analyzer (GA2000, Geotechnical Instruments) was used for the outdoor measurements. The device has measuring ranges of $0-70 \%$ for $\mathrm{CH}_{4}, 0-60 \%$ for $\mathrm{CO}_{2}$, and $0-25 \%$ for $\mathrm{O}_{2}$, with an accuracy level of $0.5 \%$ (in a measuring range of up to $5 \%$ ) or $1 \%$ (in the range of $5-15 \%$ ). The analyzer was calibrated by the producer and was frequently calibrated on-site using reference gas. The results from the portable landfill gas analyzer GA2000 were compared with stationary laboratory gas chromatography measurements (Shimadzu GC-2014, Loftfields Analytical Solutions PROBE65).

The water content, temperature, and $\mathrm{pH}$ in the $50 \mathrm{~cm}$-deep layer of the biocover were measured in October 2015 at the points shown in Figure 3b. The temperature was measured in situ by type k thermocouples with a 6802 II Dual Channel Digital Thermometer. The sensor was placed in soil at the bottom of the borehole right after completing the $0.5 \mathrm{~m}$ borehole. For moisture and $\mathrm{pH}$ measurements, samples from the biocover were taken to the laboratory. For the moisture measurement, the samples were dried at $105^{\circ} \mathrm{C}$. For the measurement of the $\mathrm{pH}, 5 \mathrm{~g}$ of soil and $50 \mathrm{~mL}$ of distilled water $(1: 10 \mathrm{w} / \mathrm{v})$ were mixed and shaken on an orbital shaker $(140 \mathrm{rpm})$ for $1 \mathrm{~h}$ to equilibrate the solution with solids [77]. The $\mathrm{pH}$ was measured with a multi-parameter meter $\mathrm{pH} / \mathrm{Cond} 340 \mathrm{i}(\mathrm{WTW})$. All the measurements were performed in triplicate.

ArcGIS for Desktop drawings was used to form location maps of the measurement points. The Estonian Land Board orthophotograph [78] was used as the base map. The interpolation of the 
measurement results was carried out using the natural neighbor method. Spatial interpolation can be considered to be a good general-purpose interpolation technique. The distribution of $\mathrm{CH}_{4}$ and $\mathrm{CO}_{2}$ included a total of 24 measurement points, with an average point density of about 13 points per hectare-i.e., each point represented an average area of about $750 \mathrm{~m}^{2}$.

\section{Results}

In the Kudjape landfill, traces of methane were found from two points (P4 and P22, Figure 3a) at the surface out of 29 measuring points-i.e., $7 \%$ of the points. At P22, the maximum concentration of methane $(2.1 \%)$ in the total landfill gas composition was measured in July 2015 (Figure 5a), while all the following results were lower: $0.9 \%$ in August, $0.7 \%$ in September, $1.5 \%$ in October, $0.0 \%$ in December, and $0.2 \%$ in April (Figure 5). Methane emissions did not occur in December (Figure 5e), due to the frozen surface layer. A downward trend, similar to that shown at point P22, also occurred at point P4.
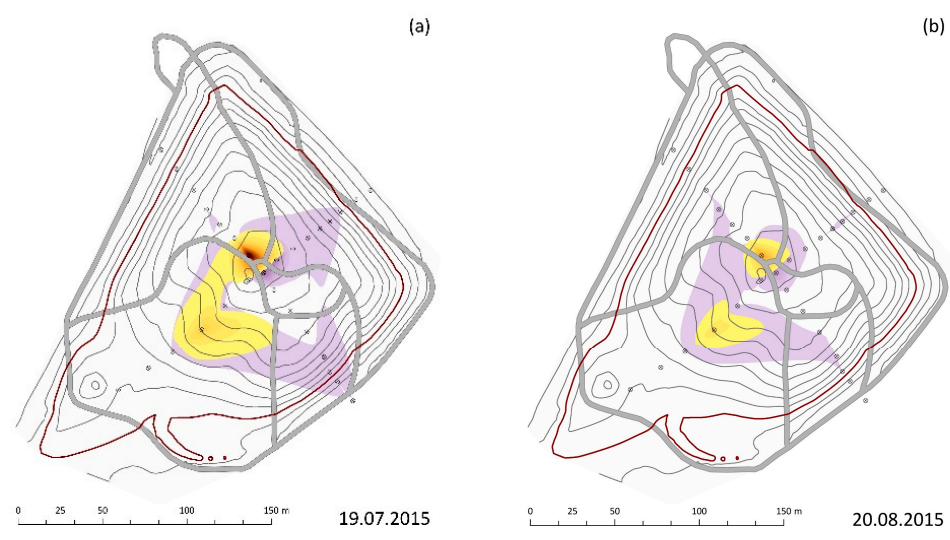

(b)
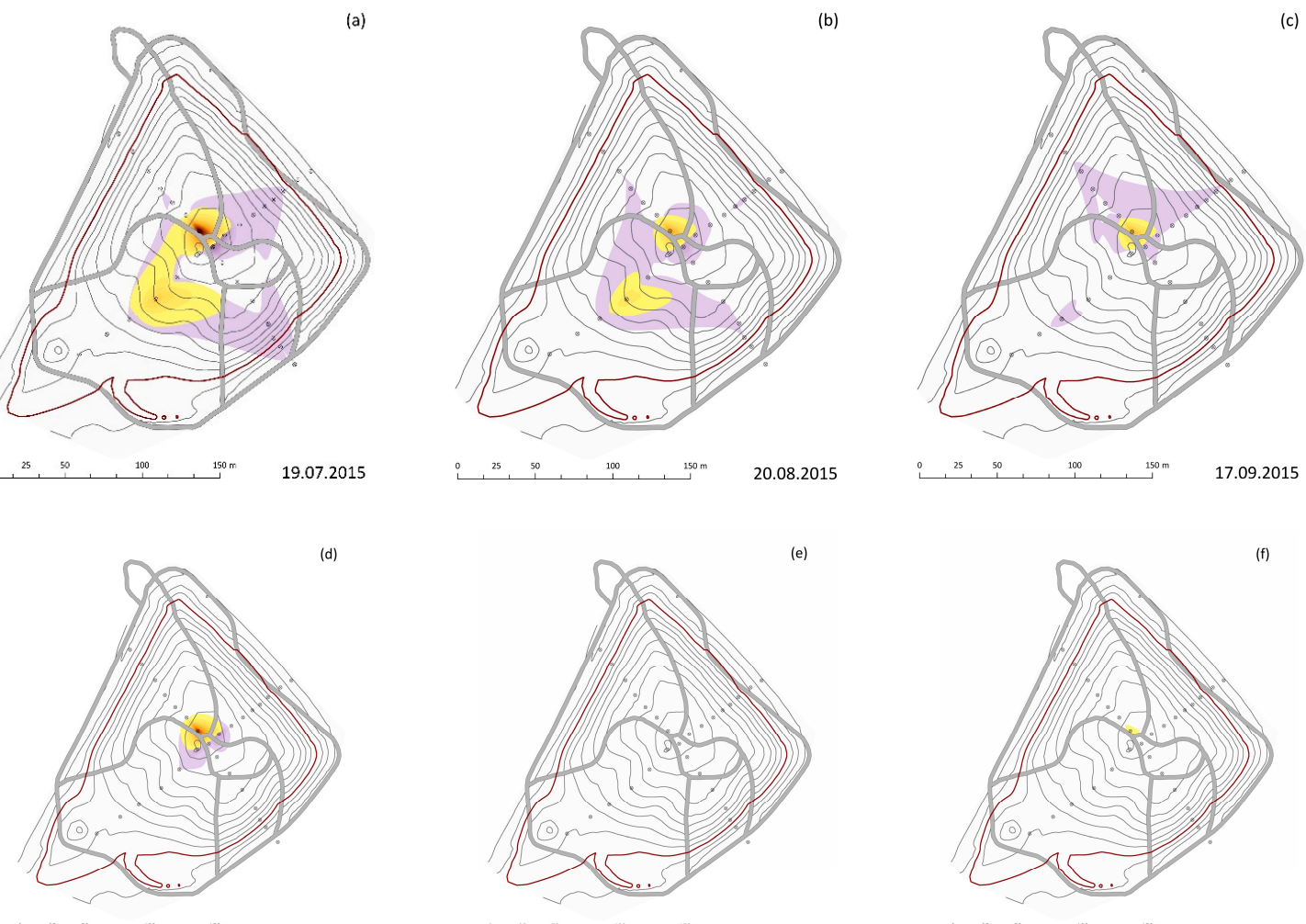

(e)

(f)
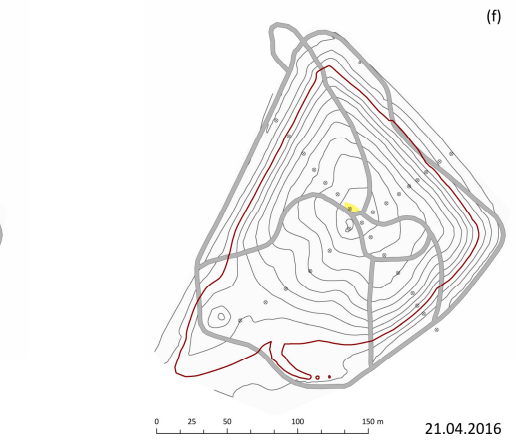

$\mathrm{CH} 4$ (\%)
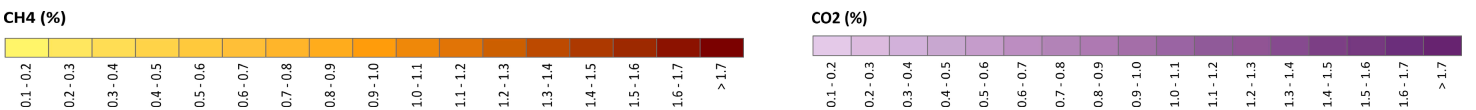

Figure 5. The $\mathrm{CH}_{4}$ and $\mathrm{CO}_{2}$ emissions from the surface of the landfill. (a) July 19, 2015; (b) August 20, 2015; (c) September 17, 2015; (d) October 17, 2015; (e) December 27, 2015; (f) April 21, 2016.

Changes in the carbon dioxide emission peaks were similar to the changes in the methane peaks. The highest result (1.0\%) from the surface was measured in July (Figure 5a), while the subsequent results were lower: $0.7 \%$ in August, $0.6 \%$ in September, $0.7 \%$ in October, $0.0 \%$ in December, and $0.2 \%$ in April.

Emissions of methane in the Kudjape landfill do not pose any occupational risk, as they have never reached explosive levels. Methane becomes explosive at a concentration of 5\% in air [79], whereas the maximum recorded value of methane at the Kudjape landfill was $2.1 \%$, and it reduced over time.

A comparison of the results from the biocover surface expressed in \% measured by the field instrument (Figure 6a versus Figure 6d) and lab instrument (Figure 6b,e) demonstrated 
similar spatial distributions of methane and carbon dioxide. Laboratory data expressed in ppb, however, provide high-resolution information (Figure 7).
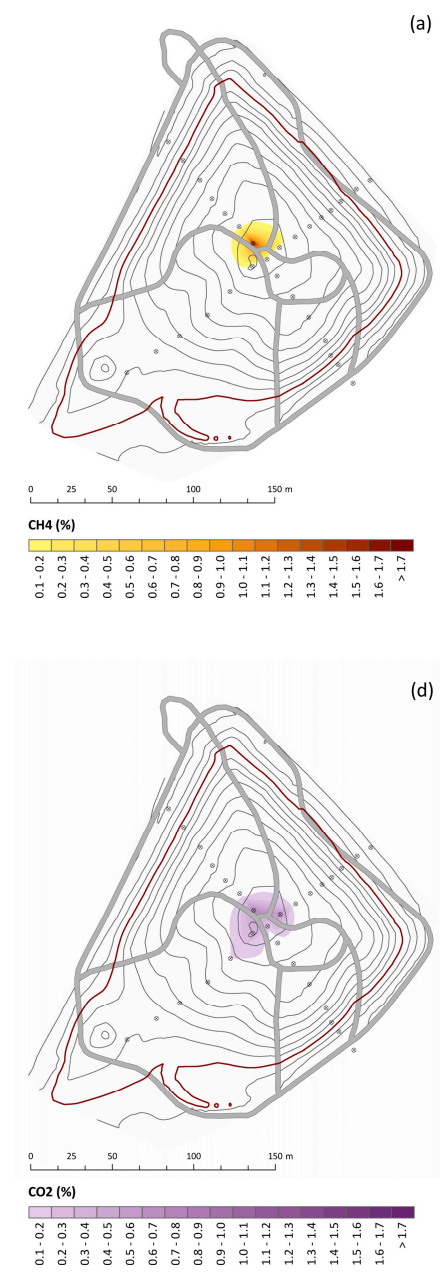

(d)

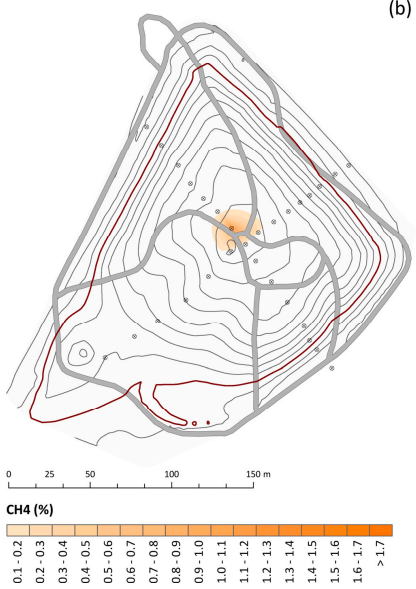

(e)

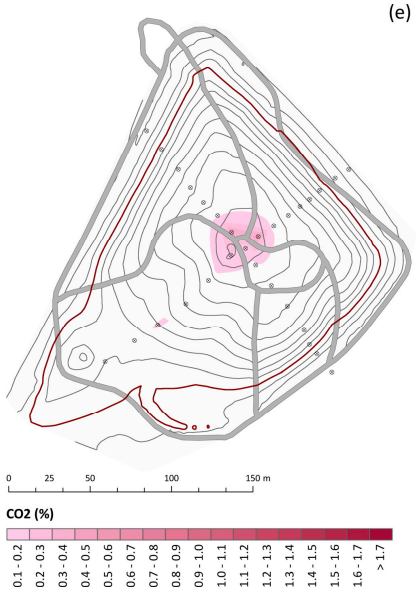

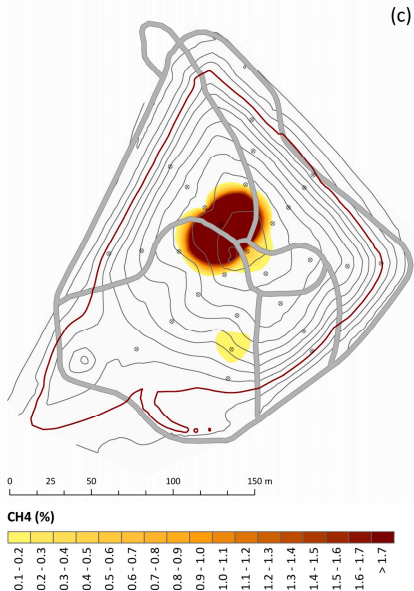

Figure 6. Methane and carbon dioxide emission from the landfill surface and $50 \mathrm{~cm}$ deep in the biocover, October 17, 2015. (a) In situ $\mathrm{CH}_{4}$ from surface; (b) lab $\mathrm{CH}_{4}$ from surface; (c) in-situ $\mathrm{CH}_{4} 50 \mathrm{~cm}$ deep; (d) in-situ $\mathrm{CO}_{2}$ from surface; (e) lab $\mathrm{CO}_{2}$ from surface; (f) in-situ $\mathrm{CO}_{2} 50 \mathrm{~cm}$ deep.

Based on the laboratory analysis, the average methane content from all 29 measurement points of the Kudjape landfill was $0.04 \%$. Methane was found at points P22, P8, P4, P7, and P6, where it was $1.1 \%, 0.08 \%, 0.07 \%, 0.05 \%$, and $0.01 \%$, respectively (Figure $6 \mathrm{~b}$ ). Measuring points P6, P7, and P8 are located at the tip of the landfill, similar to P22, where the methane concentration was the largest as measured by portable equipment. The concentrations obtained from the remaining measuring points were mostly smaller.

The carbon dioxide concentrations from the surface of the landfill, analyzed by the laboratory, ranged from $0.008 \%$ to $0.44 \%$ for all points. The highest concentrations were measured at P8 and P22: $0.44 \%$ and $0.40 \%$. For carbon dioxide, there were only positive emission values, which means that the surface does not absorb more atmospheric carbon dioxide.

Measurements taken from $0.5 \mathrm{~m}$ deep in the biocover showed the highest value of methane in the K6 borehole-12.8\% (Figure 6c). However, also in wells K5 and K19 the methane value was $0.6 \%$ and $0.2 \%$, respectively. Carbon dioxide was present in all 29 wells (Figure $6 \mathrm{f}$ ), ranging from $0.1 \%$ to $5.7 \%$. The highest value was measured in well $\mathrm{K} 6$. 


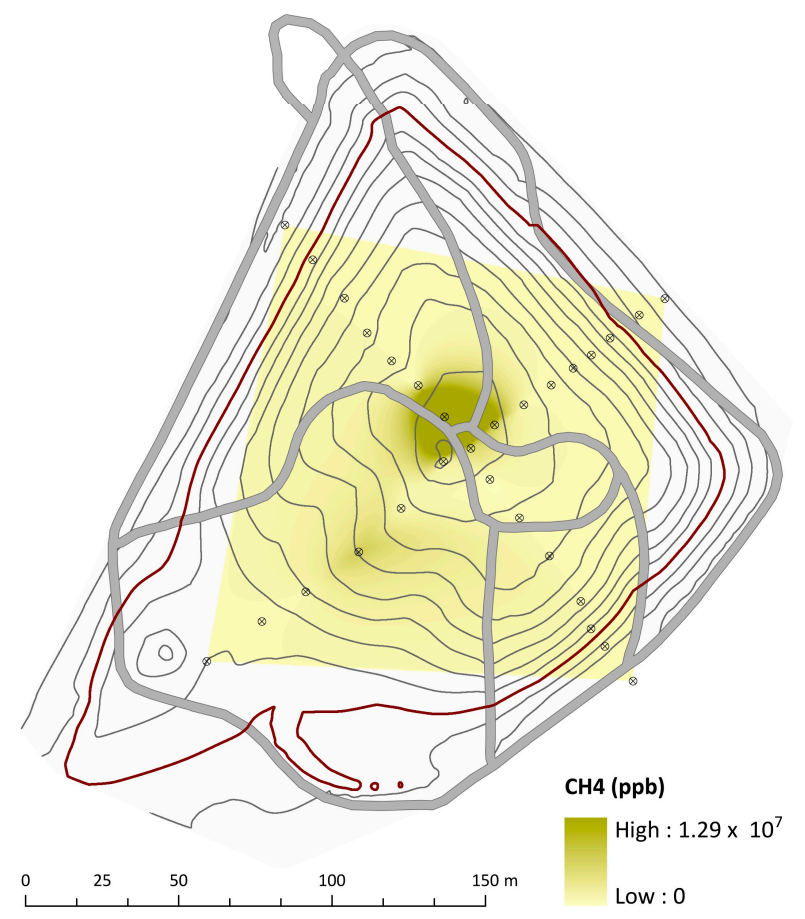

Figure 7. High-resolution laboratory data, $\mathrm{CH}_{4}$ from the surface.

The presence of methane inside the cover layer indicates that the landfill continues to produce methane. Even if the gas is produced, it is not escaping into the atmosphere. In October, the maximum value of methane released through the surface of the biocover was about six times lower than the maximum methane measured within the biocover. This shows that bacteria are supplied with enough methane to support their survival, and most of the methane is also degraded. A sufficient amount of methane input into the biocover is a prerequisite for the active survival of methanotrophs and the effective degradation of methane.

At a depth of $50 \mathrm{~cm}$, the moisture content (Figure 8a) of the biocover material was $8.2-55.9 \%$, with an average value of $21.8 \%$. The K6 borehole, which had the highest leakage of methane, also had the highest moisture content. This shows the migration of moisture by gas. An area of high moisture content was also found on the northeast of the landfill, where methane emissions were not observed.
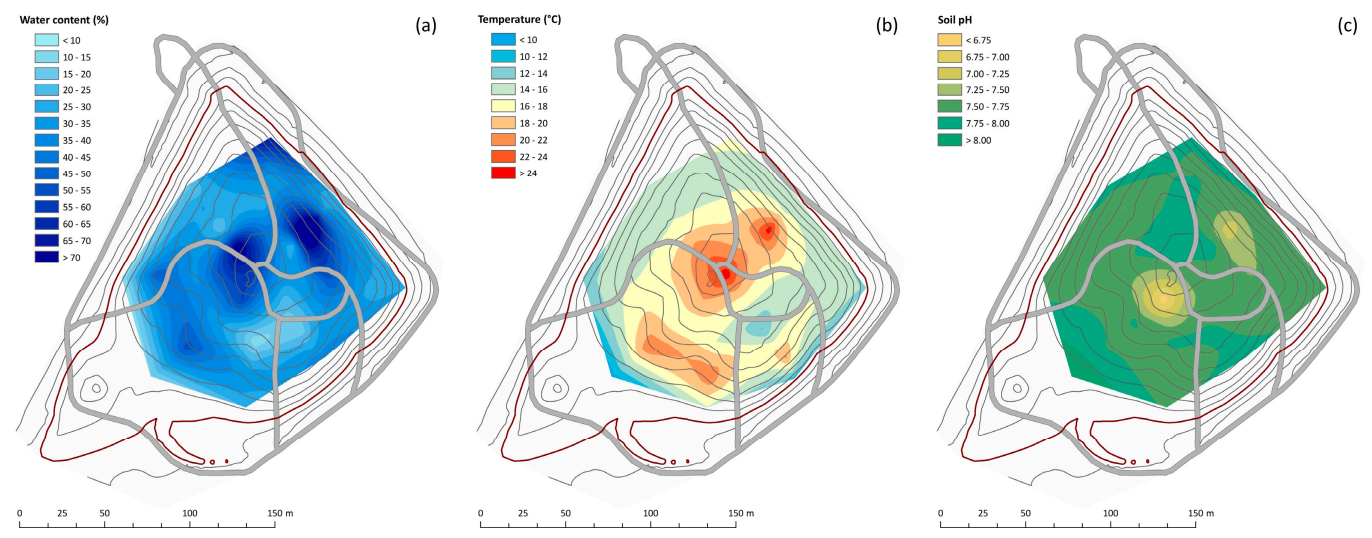

Figure 8. Water content (a), temperature (b), and $\mathrm{pH}(\mathbf{c})$ in the $50 \mathrm{~cm}$-deep layer of the biocover, October 17, 2015.

In October, the temperature of the biocover ranged from 9.1 to $25.2^{\circ} \mathrm{C}$ (Figure $8 \mathrm{~b}$ ). The moisture-rich areas of the biocover coincided with areas of elevated temperature (Figure $8 \mathrm{a}, \mathrm{b}$ ). The area with the 
highest temperature on the surface was at the top of the landfill, but it did not fully cover the largest methane-emitted sampling point. Higher temperatures were measured by the northeast and south slopes of the landfill, where there was also the area with the maximum soil moisture. There was no correlation between the presence of methane emissions and the temperature of the surface of the cover.

At measuring points P4 and P22, a slight interaction was observed between the temperature and the reductions in methane and carbon dioxide emissions. The smallest amounts of methane and carbon dioxide were measured in December, when the air temperature $\left(1.1^{\circ} \mathrm{C}\right)$ was the lowest during all measuring events. Between December and March, the ground was frozen and covered with snow, resulting in no methane escaping from the soil, which led to the higher methane emissions measured in the spring when the snow had melted. During the measurements carried out in December, there was no snow cover at the Kudjape landfill; however, the temperature was below zero, at least during the nights. Methane, which did not decompose in the deeper layers, could later dissipate in the upper parts of the biocover.

The $\mathrm{pH}$ measured in the boreholes at a depth of $0.5 \mathrm{~m}$ was in the range of 6.6 to 8.3 (Figure $8 \mathrm{c}$ ). The biocover material was found to be more acidic at higher elevations of the landfill compared with the lower periphery, but this did not completely coincide with the elevated methane emission area.

\section{Discussion}

In the Kudjape landfill, gas was measured from the surface at 29 measuring points, and traces of methane were found in $7 \%$ of them. To compare, at the Aikkala landfill, located in a comparable climate in the South of Finland where the biocover is a mixture of sludge compost and peat, Einola et al. [45] measured the methane emissions from 25 measuring points with similar equipment and found methane in $16 \%$ to $32 \%$ of the measured points at various times.

The presence of carbon dioxide can be a sign of living activity through the airborne breathing of organisms or by microbiological degradation of methane. At the Kudjape landfill, emissions from carbon dioxide were found at less than $55 \%$ of the measurement points, depending on the time of the measurement. At the Aikkala landfill, Einola et al. [45] found carbon dioxide emissions at $76 \%$ to $100 \%$ of the measuring points depending on the measurement time.

Detailed research on the phenomenon that atmospheric methane can be absorbed in the upper layer of the biocover, as described by Stern et al. [55] and observed in the current study, is required. This may indicate the active survival of methanotrophs and the capability to oxidize methane captured from the atmosphere in addition to the methane released from the landfill.

In terms of meteorological indicators, the biggest influences on the methane emissions are air temperature and precipitation $[7,8]$, which influence the temperature of the upper layers of the biocover and its moisture content, respectively. The upper values of humidity were found to be within the recommendations of Huber-Humer et al. [42]: $30-50 \%$. The lower values were clearly too low. Excessively dry areas may require irrigation. The average moisture content was $21.8 \%$; however, this is compatible with the acceptable moisture content for methane oxidation (18-24\%) described by Scheutz and Kjeldsen [62].

The recorded temperature of the biocover was 9.1 to $25.2^{\circ} \mathrm{C}$ (Figure 8b), which is below the optimum temperature of $30^{\circ} \mathrm{C}$ found by Scheutz and Kjeldsen [62]. The temperature range, however, did not fall below the tolerance of methanotrophs.

The smallest amounts of methane and carbon dioxide were measured in December. A similar trend between the air temperature and methane emissions was found by Park and Shin [80], where the methane emissions were lower in winter compared to in spring and summer. According to the study, the reason for the lower methane concentrations was the shrinking of the soil pores caused by the low temperatures. Börjesson and Svensson [28] also measured low methane emissions in winter. Between December and March, the ground was frozen and covered with snow, resulting in no methane escaping from the soil, which led to the higher methane emissions measured in the spring when the snow had 
melted. At lower temperatures, it was observed that the active oxidation layer moved deeper into the biocover [42], which may be the reason for the lack of measured methane.

The $\mathbf{p H}$ measured in the biocover was in line with the results of Huber-Humer et al. [42] (Table 1) and could support the life of methanotrophs.

\section{Conclusions}

Methane emissions from landfills should be minimized by active or passive gas collection systems. Microbial methane oxidation in a semi-permeable bioactive cover layer offers an alternative option for reducing greenhouse gases in situ. A fine $<40 \mathrm{~mm}$ soil-like fraction was excavated using landfill mining technology and used as a biocover at the Kudjape landfill in Estonia.

The spatial distribution of gases through the biocover was measured two years after the cover layer was installed, from July 2015 to April 2016. Methane and carbon dioxide emissions were measured six times on the surface at 29 measuring points, as well as once at a depth of $0.5 \mathrm{~m}$. The highest values of both gases from the surface were recorded in July 2015-1.0\% for $\mathrm{CO}_{2}$ and $2.1 \%$ for $\mathrm{CH}_{4}$. The results showed seasonal fluctuations in the compositions of gases and a decreasing trend in the concentration of $\mathrm{CH}_{4}$.

The gas measurement in the field was accompanied by laboratory analyses for one series of measurements. The distribution pattern of gases was similar according to field and laboratory measurements, suggesting that both methods are equally reliable.

Deeper in the cover layer, the methane concentration increased, as expected. This shows that after landfill gas is generated, it migrates upwards from the deeper layers but does not escape to the atmosphere.

The cover layer is a dynamic system - its properties are continuously changing over time, and they depend on climatic conditions. The water content, $\mathrm{pH}$, and temperature of the biocover were measured once at a depth of $50 \mathrm{~mm}$. Interestingly, the hotspots of all three parameters occurred at nearly identical places in the cover. The highest methane values were measured at the top of the landfill, where there was also a clearly higher temperature due to the chimney effect. The same spot had a larger water content due to the transportation of moisture by gases. It is not clear whether the higher temperature and moisture content occurred because of gas degradation, or whether, vice versa, the higher gas values occurred because of the elevated temperatures and moisture. Nevertheless, the design of the methane oxidation layer was appropriate in this study. Spots with higher concentrations of methane suggest the need for repair actions, which should be considered normal correction measures and not a design failure.

The in situ degradation of methane offers a sound solution for greenhouse gas reduction in small to medium sized landfills where gas production is low. The effect that is achieved using biocovers is fully in line with UN Sustainable Development Goal 13: take urgent action to combat climate change and its impacts. The proposed cover design has great potential for reducing $\mathrm{CH}_{4}$ emissions in landfills using elements of circular economy-instead of wasting natural soils and using expensive synthetic liners for the construction of an impermeable final cover layer, functional waste-derived materials can be used for building biocovers. Landfill mining offers a sound alternative for producing substrates for biocovers in dumpsites or landfills where material with a low permeability, or any cover material at all, is not available.

Author Contributions: Conceptualization, K.-M.P. and M.K.; methodology, K.-M.P., M.K., and V.K.; software and validation, O.T.; formal analysis, K.O.; investigation, K.-M.P.; resources, M.K.; writing-original draft preparation, K.-M.P., M.K., K.O., V.K., and T.T.; writing-review and editing, K.-M.P.; visualization, O.T.; supervision, M.K., Y.J., V.K., and T.T.; project administration, K.-M.P. and M.K.; funding acquisition, M.K. All authors have read and agreed to the published version of the manuscript.

Funding: This research was funded by the Estonian Ministry of Education and Research, P170055MIVE: "The implementation of the circular economy principles on utilisation of previously deposited waste as resources and energy and the use of stabilized fine fraction as methane degradation layer to minimise emissions of greenhouse gases"; and by the European Cohesion Fund, Estonian Environmental Investment Centre, and local authorities via 
Vealeidja OÜ, 8-2/T12082MIVE: “Monitoring of Kudjape landfill closure works". The contribution of a Swedish Institute funded project "Closing the Life Cycle of Landfills-Landfill Mining in the Baltic Sea Region for future" (Linnaeus University, Sweden) is acknowledged. COST Action CA15115 Mining the European Anthroposphere (MINEA) is acknowledged for providing grounds for networking.

Acknowledgments: The following students are acknowledged for their contributions to field and lab work: Merilin Heinsoo for gas sampling, Kati Tammjärv for assistance, Kertu Sapelkov for laboratory analysis, Alar Teemusk from the University of Tartu for laboratory gas analyses, and Liis Koppel for the landscape project. Valdo, Mihkel, Olavi, Rein-Erik, and field personnel are acknowledged for their work and encouragement on scientific research at the site.

Conflicts of Interest: The authors declare no conflict of interest.

\section{References}

1. Staley, B.F.; Xu, F.; Cowie, S.J.; Barlaz, M.A.; Hater, G.R. Release of trace organic compounds during the decomposition of municipal solid waste components. Environ. Sci. Technol. 2006, 40, 5984-5991. [CrossRef] [PubMed]

2. Brosseau, J.; Heitz, M. Trace gas compound emissions from municipal landfill sanitary sites. Atmos. Environ. 1994, 28, 285-293. [CrossRef]

3. IPCC. Climate Change 2007: The Physical Science Basis: Contribution of Working Group I to the Fourth Assessment Report of the Intergovernmental Panel on Climate Change; Solomon, S., Qin, D., Manning, M., Marquis, M., Averyt, K., Tignor, M., Miller, H.L., Chen, Z., Eds.; Cambridge University Press: Cambridge, UK; New York, NY, USA, 2007.

4. Kammann, C.; Ratering, S.; Eckhard, C.; Müller, C. Biochar and hydrochar effects on greenhouse gas (carbon dioxide, nitrous oxide, and methane) fluxes from soils. J. Environ. Qual. 2012, 41, 1052-1066. [CrossRef] [PubMed]

5. Majdinasab, A.; Yuan, Q. Performance of the biotic systems for reducing methane emissions from landfill sites: A review. Ecol. Eng. 2017, 104, 116-130. [CrossRef]

6. Huber-Humer, M. International research into landfill gas emissions and mitigation strategies IWWG working group “CLEAR”. Waste Manag. 2004, 24, 425-427. [CrossRef] [PubMed]

7. Barlaz, M.A.; Ham, R.K.; Schaefer, D.M.; Isaacson, R. Methane production from municipal refuse: A review of enhancement techniques and microbial dynamics. Crit. Rev. Environ. Control 1990, 19, 557-584. [CrossRef]

8. Machado, S.L.; Carvalho, M.F.; Gourc, J.-P.; Vilar, O.M.; do Nascimento, J.C.F. Methane generation in tropical landfills: Simplified methods and field results. Waste Manag. 2009, 29, 153-161. [CrossRef]

9. Guermoud, N.; Ouadjnia, F.; Abdelmalek, F.; Taleb, F.; Addou, A. Municipal solid waste in mostaganem city (western algeria). Waste Manag. 2009, 29, 896-902. [CrossRef]

10. Chan, G.Y.S.; Chu, L.M.; Wong, M.H. Effects of leachate recirculation on biogas production from landfill co-disposal of municipal solid waste, sewage sludge and marine sediment. Environ. Pollut. 2002, 118, 393-399. [CrossRef]

11. Mehta, R.; Barlaz, M.; Yazdani, R.; Augenstein, D.; Bryars, M.; Sinderson, L. Refuse decomposition in the presence and absence of leachate recirculation. J. Environ. Eng. 2002, 128, 228-236. [CrossRef]

12. Hartz, K.E.; Klink, R.E.; Ham, R.K. Temperature effects: Methane generation from landfill samples. J. Environ. Eng. Div. 1982, 108, 629-638.

13. Mata-Alvarez, J.; Martinez-Viturtia, A. Laboratory simulation of municipal solid waste fermentation with leachate recycle. J. Chem. Technol. Biotechnol. 1986, 36, 547-556. [CrossRef]

14. Cambaliza, M.; Shepson, P.; Bogner, J.; Caulton, D.; Stirm, B.; Sweeney, C.; Montzka, S.; Gurney, K.; Spokas, K.; Salmon, O.; et al. Quantification and source apportionment of the methane emission flux from the city of indianapolis. Elem. Sci. Anthr. 2015, 3, 000037. [CrossRef]

15. Foster-Wittig, T.A.; Thoma, E.D.; Green, R.B.; Hater, G.R.; Swan, N.D.; Chanton, J.P. Development of a mobile tracer correlation method for assessment of air emissions from landfills and other area sources. Atmos. Environ. 2015, 102, 323-330. [CrossRef]

16. Mønster, J.; Samuelsson, J.; Kjeldsen, P.; Scheutz, C. Quantification of methane emissions from 15 danish landfills using the mobile tracer dispersion method. Waste Manag. 2015, 35, 177-186. [CrossRef] 
17. Mønster, J.G.; Samuelsson, J.; Kjeldsen, P.; Rella, C.W.; Scheutz, C. Quantifying methane emission from fugitive sources by combining tracer release and downwind measurements-A sensitivity analysis based on multiple field surveys. Waste Manag. 2014, 34, 1416-1428. [CrossRef]

18. Scheutz, C.; Samuelsson, J.; Fredenslund, A.M.; Kjeldsen, P. Quantification of multiple methane emission sources at landfills using a double tracer technique. Waste Manag. 2011, 31, 1009-1017. [CrossRef]

19. Babilotte, A.; Lagier, T.; Fiani, E.; Taramini, V. Fugitive methane emissions from landfills: Field comparison of five methods on a French landfill. J. Environ. Eng. 2010, 136, 777-784. [CrossRef]

20. Goldsmith, C.; Chanton, J.; Abichou, T.; Swan, N.; Green, R.; Haters, G. Methane emissions from 20 landfills across the United States using vertical radial plume mapping. J. Air Waste Manag. Assoc. 2012, 62, 183-197. [CrossRef]

21. Mackie, K.R.; Cooper, C. Landfill gas emission prediction using voronoi diagrams and importance sampling. Environ. Model. Softw. 2009, 24, 1223-1232. [CrossRef]

22. Oonk, H. Literature Review: Methane from Landfills, Methods to Quantify Generation, Oxidation and Emission; OonKAY: Apeldoorn, The Netherlands, 2010; pp. 1-75.

23. Figueroa, V.K.; Mackie, K.R.; Guarriello, N.; Cooper, C.D. A robust method for estimating landfill methane emissions. J. Air Waste Manag. Assoc. 2009, 59, 925-935. [CrossRef] [PubMed]

24. Bogner, J.; Meadows, M.; Czepiel, P. Fluxes of methane between landfills and the atmosphere: Natural and engineered controls. Soil Use Manag. 1997, 13, 268-277. [CrossRef]

25. Scheutz, C.; Kjeldsen, P.; Bogner, J.E.; Visscher, A.D.; Gebert, J.; Hilger, H.A.; Huber-Humer, M.; Spokas, K. Microbial methane oxidation processes and technologies for mitigation of landfill gas emissions. Waste Manag. Res. 2009, 27, 409-455. [CrossRef] [PubMed]

26. Abichou, T.; Chanton, J.; Powelson, D.; Fleiger, J.; Escoriaza, S.; Lei, Y.; Stern, J. Methane flux and oxidation at two types of intermediate landfill covers. Waste Manag. 2006, 26, 1305-1312. [CrossRef]

27. Kjeldsen, P.; Dalager, A.; Broholm, K. Attenuation of methane and non methane organic compounds in landfill gas affected soils. J. Air Waste Manag. Assoc. 1997, 47, 1268-1275. [CrossRef]

28. Börjesson, G.; Svensson, B.H. Seasonal and diurnal methane emissions from a landfill and their regulation by methane oxidation. Waste Manag. Res. 1997, 15, 33-54.

29. Beaven, R.P.; Knox, K.; Gronow, J.R.; Hjelmar, O.; Greedy, D.; Scharff, H. A new economic instrument for financing accelerated landfill aftercare. Waste Manag. 2014, 34, 1191-1198. [CrossRef]

30. Knox, K.; Braithwaite, P.; Caine, M.; Croft, B. Brogborough landfill test cells: The final chapter-A study of landfill completion in relation to final storage quality (FSQ) criteria. In Proceedings of the Sardinia Symposium, Santa Margherita di Pula, Cagliari, Italy, 3-7 October 2005; Volume 1.

31. Laner, D.; Crest, M.; Scharff, H.; Morris, J.W.F.; Barlaz, M.A. A review of approaches for the long-term management of municipal solid waste landfills. Waste Manag. 2012, 32, 498-512. [CrossRef]

32. Rowe, R.K. Contaminant impact assessment and the contaminant lifespan of landfills. Can. J. Civ. Eng. 1991, 18, 244-253. [CrossRef]

33. Ontario Regulation 232/98 Landfilling Sites. Available online: https://www.ontario.ca/laws/regulation/980232 (accessed on 13 January 2020).

34. Burton, S.A.Q.; Beaven, R.P.; White, J.K. The effect of moisture content in controlling landfill gas production and its application to a model for landfill refuse decomposition. In Proceedings of the Waste 2004, Stratford-upon-Avon, UK, 22-24 September 2004; Volume 1, pp. 333-342.

35. Sébastien, P.; Chenu, D.; Quintard, M.; Lefebvre, X. A logistic model for the prediction of the influence of water on the solid waste methanization in landfills. Biotechnol. Bioeng. 2007, 97, 473-482.

36. Meima, J.A.; Naranjo, N.M.; Haarstrick, A. Sensitivity analysis and literature review of parameters controlling local biodegradation processes in municipal solid waste landfills. Waste Manag. 2008, 28, 904-918. [CrossRef] [PubMed]

37. Townsend, T.G.; Miller, W.L.; Hyung-Jib, L.; Earle, J.F.K. Acceleration of landfill stabilization using leachate recycle. J. Environ. Eng. 1996, 122, 263-268. [CrossRef]

38. Bareither Christopher, A.; Benson Craig, H.; Barlaz Morton, A.; Edil Tuncer, B.; Tolaymat Thabet, M. Performance of north American bioreactor landfills. I: Leachate hydrology and waste settlement. J. Environ. Eng. 2010, 136, 824-838. [CrossRef]

39. Scharff, H.; Zomeren, A.; van der Sloot, H. Landfill sustainability and aftercare completion criteria. Waste Manag. Res. 2010, 29, 30-40. [CrossRef] [PubMed] 
40. Kattenberg, W.J.; van der Sloot, H.A.; Heimovaara, T.J. New Dutch legislation to allow research of natural biodegradation at landfills. In Proceedings of the Sardinia Symposium, Santa Margherita di PulaCagliari, Italy, 30 September-4 October 2013; Volume 1.

41. Hilger, H.; Humer, M. Biotic landfill cover treatments for mitigating methane emissions. Environ. Monit. Assess. 2003, 84, 71-84. [CrossRef] [PubMed]

42. Huber-Humer, M.; Röder, S.; Lechner, P. Approaches to assess biocover performance on landfills. Waste Manag. 2009, 29, 2092-2104. [CrossRef]

43. University of NSW, School of Civil and Environmental Engineering. Handbook for the Design, Construction, Operation, Monitoring and Maintenance of a Passive Landfill Gas Drainage and Biofiltration System, 1st ed.; Department of Environment, Climate Change and Water NSW: Sydney, Australia, 2010; ISBN 978-1-74232-097-7.

44. Huber-Humer, M.; Gebert, J.; Hilger, H. Biotic systems to mitigate landfill methane emissions. Waste Manag. Res. 2008, 26, 33-46. [CrossRef]

45. Einola, J.; Sormunen, K.; Lensu, A.; Leiskallio, A.; Ettala, M.; Rintala, J. Methane oxidation at a surface-sealed boreal landfill. Waste Manag. 2009, 29, 2105-2120. [CrossRef]

46. Pedersen, G.B. Processes in a Compost Based Landfill Biocover; Methane Emission, Transport and Oxidation. Ph.D. Thesis, Department of Environmental Engineering, Technical University of Denmark, Lyngby, Denmark, 2010.

47. Einola, J.-K.M.; Karhu, A.E.; Rintala, J.A. Mechanically-biologically treated municipal solid waste as a support medium for microbial methane oxidation to mitigate landfill greenhouse emissions. Waste Manag. 2008, 28, 97-111. [CrossRef]

48. Kightley, D.; Nedwell, D.B.; Cooper, M. Capacity for methane oxidation in landfill cover soils measured in laboratory-scale soil microcosms. Appl. Env. Microbiol. 1995, 61, 592-601. [CrossRef]

49. Boeckx, P.; van Cleemput, O.; Villaralvo, I. Methane emission from a landfill and the methane oxidising capacity of its covering soil. Soil Biol. Biochem. 1996, 28, 1397-1405. [CrossRef]

50. Chanton, J.; Liptay, K. Seasonal variation in methane oxidation in a landfill cover soil as determined by an in situ stable isotope technique. Glob. Biogeochem. Cycles 2000, 14, 51-60. [CrossRef]

51. Börjesson, G.; Chanton, J.; Svensson, B.H. Methane oxidation in two swedish landfill covers measured with carbon-13 to carbon-12 isotope ratios. J. Environ. Qual. 2001, 30, 369. [CrossRef] [PubMed]

52. Sadasivam, B.Y.; Reddy, K.R. Landfill methane oxidation in soil and bio-based cover systems: A review. Rev. Environ. Sci. Biotechnol. 2014, 13, 79-107. [CrossRef]

53. Börjesson, G.; Sundh, I.; Tunlid, A.; Svensson, B.H. Methane oxidation in landfill cover soils, as revealed by potential oxidation measurements and phospholipid fatty acid analyses. Soil Biol. Biochem. 1998, 30, 1423-1433. [CrossRef]

54. Scheutz, C.; Pedicone, A.; Pedersen, G.B.; Kjeldsen, P. Evaluation of respiration in compost landfill biocovers intended for methane oxidation. Waste Manag. 2011, 31, 895-902. [CrossRef]

55. Hrad, M.; Huber-Humer, M.; Wimmer, B.; Reichenauer, T.G. Design of top covers supporting aerobic in situ stabilization of old landfills_An experimental simulation in lysimeters. Waste Manag. 2012, 32, 2324-2335. [CrossRef]

56. Pecorini, I.; Rossi, E.; Iannelli, R. Mitigation of methane, NMVOCs and odor emissions in active and passive biofiltration systems at municipal solid waste landfills. Sustainability 2020, 12, 3203. [CrossRef]

57. Stern, J.C.; Chanton, J.; Abichou, T.; Powelson, D.; Yuan, L.; Escoriza, S.; Bogner, J. Use of a biologically active cover to reduce landfill methane emissions and enhance methane oxidation. Waste Manag. 2007, 27, 1248-1258. [CrossRef]

58. Mei, C.; Yazdani, R.; Han, B.; Mostafid, M.E.; Chanton, J.; Vander Gheynst, J.; Imhoff, P. Performance of green waste biocovers for enhancing methane oxidation. Waste Manag. 2015, 39, 205-215. [CrossRef]

59. Einola, J.-K.M.; Sormunen, K.M.; Rintala, J.A. Methane oxidation in a boreal climate in an experimental landfill cover composed from mechanically-biologically treated waste. Sci. Total Environ. 2008, 407, 67-83. [CrossRef] [PubMed]

60. Jain, P.; Townsend, T.G.; Johnson, P. Case study of landfill reclamation at a Florida landfill site. Waste Manag. 2013, 33, 109-116. [CrossRef] [PubMed]

61. He, R.; Ruan, A.; Jiang, C.; Shen, D. Responses of oxidation rate and microbial communities to methane in simulated landfill cover soil microcosms. Bioresour. Technol. 2008, 99, 7192-7199. [CrossRef] [PubMed] 
62. Abushammala, M.F.M.; Basri, N.E.A.; Kadhum, A.A.H.; Basri, H.; El-Shafie, A.H.; Sharifah Mastura, S.A. Evaluation of methane generation rate and potential from selected landfills in Malaysia. Int. J. Environ. Sci. Technol. 2014, 11, 377-384. [CrossRef]

63. Einola, J.-K.M.; Kettunen, R.H.; Rintala, J.A. Responses of methane oxidation to temperature and water content in cover soil of a boreal landfill. Soil Biol. Biochem. 2007, 39, 1156-1164. [CrossRef]

64. Scheutz, C.; Kjeldsen, P. Environmental factors influencing attenuation of methane and hydrochlorofluorocarbons in landfill cover soils. J. Environ. Qual. 2004, 33, 72-79. [CrossRef] [PubMed]

65. Mosier, A.; Wassmann, R.; Verchot, L.; King, J.; Palm, C. Methane and nitrogen oxide fluxes in tropical agricultural soils: Sources, sinks and mechanisms. Environ. Dev. Sustain. 2004, 6, 11-49. [CrossRef]

66. Albanna, M.; Fernandes, L.; Warith, M. Methane oxidation in landfill cover soil; the combined effects of moisture content, nutrient addition, and cover thickness. J. Environ. Eng. Sci. 2007, 6, 191-200. [CrossRef]

67. Parrodi, J.C.H.; Höllen, D.; Pomberger, R. Characterization of fine fractions from landfill mining: A review of previous investigations. Detritus 2018, 2, 46. [CrossRef]

68. Kaczala, F.; Mehdinejad, M.H.; Lääne, A.; Orupõld, K.; Bhatnagar, A.; Kriipsalu, M.; Hogland, W. Leaching characteristics of the fine fraction from an excavated landfill: Physico-chemical characterization. J. Mater. Cycles Waste Manag. 2017, 19, 294-304. [CrossRef]

69. Villoslada, M.; Bunce, R.G.H.; Sepp, K.; Jongman, R.H.G.; Metzger, M.J.; Kull, T.; Raet, J.; Kuusemets, V.; Kull, A.; Leito, A. A framework for habitat monitoring and climate change modelling: Construction and validation of the environmental stratification of estonia. Reg. Environ. Chang. 2017, 17, 335-349. [CrossRef]

70. Ideon, T. The Excavation and Sorting of Waste in Closure Works of Kudjape Landfill. Environmental IMPACT Assessment (in Estonian). Available online: http://www.kudjape.ee/arhiiv/teade14.pdf (accessed on 19 December 2019).

71. Burlakovs, J.; Kaczala, F.; Vincevica-Gaile, Z.; Rudovica, V.; Orupõld, K.; Stapkevica, M.; Bhatnagar, A.; Kriipsalu, M.; Hogland, M.; Klavins, M.; et al. Mobility of metals and valorization of sorted fine fraction of waste after landfill excavation. Waste Biomass Valorization 2016, 7, 593-602. [CrossRef]

72. Pehme, K.-M.; Kriipsalu, M. Full-scale project-From landfill to recreational area. Detritus 2018, 1, $174-179$.

73. Regulation Limit Values for Hazardous Substances in Soil RT I 2010, 57, 373. Available online: https: //www.riigiteataja.ee/akt/13348997 (accessed on 18 October 2019).

74. Pehme, K.-M.; Tamm, T.; Orupõld, K.; Kriipsalu, M. A study on methane degradation layer extracted from landfill mining. In Proceedings of the Linnaeus Eco-Tech 2014, Kalmar, Sweden, 24-26 November 2014; Volume 1, p. 85.

75. Scheutz, C.; Bogner, J.; Chanton, J.; Blake, D.; Morcet, M.; Kjeldsen, P. Comparative oxidation and net emissions of methane and selected non-methane organic compounds in landfill cover soils. Environ. Sci. Technol. 2003, 37, 5150-5158.

76. Mønster, J.; Kjeldsen, P.; Scheutz, C. Methodologies for measuring fugitive methane emissions from landfills-A review. Waste Manag. 2019, 87, 835-859. [CrossRef]

77. Pansu, M.; Gautheyrou, J. Handbook of Soil Analysis: Mineralogical, Organic and Inorganic Methods; Springer: Berlin/Heidelberg, Germany, 2006; ISBN 978-3-540-31210-9.

78. Land Board. Available online: https://geoportaal.maaamet.ee/eng/Maps-and-Data-p58.html (accessed on 8 January 2018).

79. Streese, J.; Stegmann, R. Microbial oxidation of methane from old landfills in biofilters. Waste Manag. 2003, 23, 573-580. [CrossRef]

80. Park, J.W.; Shin, H.C. Surface emission of landfill gas from solid waste landfill. Atmos. Environ. 2001, 35, 3445-3451. [CrossRef]

(C) 2020 by the authors. Licensee MDPI, Basel, Switzerland. This article is an open access article distributed under the terms and conditions of the Creative Commons Attribution (CC BY) license (http://creativecommons.org/licenses/by/4.0/). 